\title{
Erratum to: MONALISA for stochastic simulations of Petri net models of biochemical systems
}

\author{
Pavel Balazki ${ }^{1,2}$, Klaus Lindauer $^{2}$, Jens Einloft ${ }^{1}$, Jörg Ackermann ${ }^{1}$ and Ina Koch ${ }^{1 *}$
}

\section{Erratum}

After publication of the original article [1] the authors have brought to our attention that the following revisions had not been incorporated into the final published version.

In Definition 1 (Petri net): " $E \subseteq((P \times T) \cup(T \times P))$ " is the set of directed edges not " $E \subseteq((\mathrm{P} T) \cup(\mathrm{T} P))$ ". A segment of the Legend in Figure two: "A model of insulin receptor activation and recycling." was incorrect and has been removed. The Legend of Figure three was incorrect and the correct legend is: "The model of insulin receptor recycling according to Figure 2 is represented as a Petri net. Places are drawn as circles and transitions as black squares."

These mistakes have been updated in the original article as detailed in this erratum.

\begin{abstract}
Author details
'Department of Molecular Bioinformatics, Institute of Computer Science, Cluster of Excellence "Macromolecular Complexes", Johann Wolfgang Goethe-University Frankfurt am Main, Robert-Mayer-Straße 11-15, Frankfurt am Main 60325, Germany. ${ }^{2}$ Sanofi Aventis Deutschland GmbH, Industriepark Höchst H831, Frankfurt am Main 65926, Germany.
\end{abstract}

Published online: 05 November 2015

\section{Reference}

1. Balazki P, Lindauer K, Einloft J, Ackermann J, Aarum S, Koch I. MONALISA for stochastic simulations of Petri net models of biochemical systems. BMC Bioinformatics. 2015;16:215

\footnotetext{
* Correspondence: Ina.koch@bioinformatik.uni-frankfurt.de ${ }^{1}$ Department of Molecular Bioinformatics, Institute of Computer Science, Cluster of Excellence "Macromolecular Complexes", Johann Wolfgang Goethe-University Frankfurt am Main, Robert-Mayer-Straße 11-15, Frankfurt am Main 60325, Germany

Full list of author information is available at the end of the article
}

\section{Submit your next manuscript to BioMed Central and take full advantage of:}

- Convenient online submission

- Thorough peer review

- No space constraints or color figure charges

- Immediate publication on acceptance

- Inclusion in PubMed, CAS, Scopus and Google Scholar

- Research which is freely available for redistribution 